Agro-Science Journal of Tropical Agriculture, Food, Environment and Extension Volume 11 Number 2 May 2012 pp $38-45$

ISSN TIIY=7455

\title{
GRAIN YIELD ASSESSMENT OF SIX PIGEONPEA GENOTYPES IN PRODUCTION SYSTEMS AND THEIR RATOONABILITY IN A HUMID TROPICAL AGRO-ECOLOGY OF NIGERIA.
}

\author{
Dasbak $^{1}$, M.A.D. and Asiegbu ${ }^{2}$ J.E. \\ ${ }^{1}$ Garkawa, Plateau State. \\ ${ }^{2}$ Department of Crop Science, University of Nigeria Nsukka. \\ Corresponding Author: M. A. Dasbak, College of Agriculture Garkawa, PMB 001,
}

\begin{abstract}
Five improved pigeonpea genotypes obtained from ICRISAT of short-and medium-duration and a Nsukka local long-duration genotype were assessed for their grain yield in mixtures with two maize genotypes (hybrid and open pollinated types) and as sole crops in 2006 at Nsukka, Nigeria. The 2006 pigeonpea plants were maintained as sole crops for ratoon crop assessment in 2007. The pigeonpea genotypes were combined with the two maize genotypes for mixture treatments and also maintained as sole crops in a randomized complete block design (RCBD) experiment with three replications. The results showed that maize intercropping significantly $(P<0.05)$ depressed the number of primary branche, leaves and grain yield in pigeonpea in the main crop. Percentage ratoon plant survival was significantly $(P<0.05)$ higher in pigeonpea plants that were intercropped with open pollinated maize compared to those intercropped with hybrid maize and those planted as sole crops. The percentage ratoon plant survival was significantly $(P<0.05)$ higher in the long-duration pigeonpea genotype compared to those of the short- and medium-duration types which were statistically similar. The ICRISAT short- and medium-duration pigeonpea genotypes had significantly $(P<0.05)$ higher grain yield compared to the long-duration genotype in the main crop and maintained a higher grain yield in the ratoon crops too, but without any statistical significance. Ratoon crop grain yield was on the average, $63.6 \%$ of the main crop. Grain yield performance in the pigeonpea genotypes was mediumduration genotypes $>$ short-duration genotypes $>$ long-duration in both the main and ratoon crops.
\end{abstract}

Key words: Pigeonpea, genotypes, main crop, ratoon crop, grain yield.

\section{INTRODUCTION}

Pigeonpea is an erect leguminous perennial crop that is managed in agricultural systems as an annual or biennial (Snapp et al., 2003). The grains are rich source of protein and vitamins A and $\mathrm{C}$. Their introduction into feeding regime based on cereals or tubers balances the latter and combats protein deficiency linked malnutrition, which is frequent in the developing countries, especially in West Africa (Borget, 1992). Great diversity in growth and development exist among pigeonpea genotypes and seed yields obtained in traditional farming systems are reportedly low (Whiteman et al., 1985). The International Crops Research Institute for the semi-Arid Tropics (ICRISAT) has conducted extensive research on pigeonpea and released improved genotypes to farmers (Guy et al., 2001) which need to be tested under the cropping systems of the traditional resource- poor farmers for adoption. The pigeonpea genotypes are generally grouped into four categories based on growth/maturity duration thus: extra short-duration $(<105$ days $)$, shortduration (105-145 days), medium-duration (146199 days) and late-maturing (above 200 days) cultivars ( van der Maesen, 1989).

Pigeonpea are grown in a wide range of cropping systems including sole crops, intercrops with cereals, or other legumes, and with long season annuals such as castor, cotton or cassava (Willey et al., 1981). Pigeonpea ratoon crops from such systems are most often maintained from which harvests are made by the farmers. Pigeonpea/maize intercropping have been reported to be productive with land equivalent ratio (LER) values greater than one (Rao and Willey, 1980, Lingaraju et al; 2008) and is popular among traditional farmers. 
The perennial habit enables pigeonpea plants to remain vegetative even at fruit maturity and enables ratoon regrowth after harvest of the plant crop. Borget (1992) reported that it could fruit for 3-5 years, or more in favourable conditions. Wallis et al., (1981) reported that ratoon cropping of pigeonpea appears to be a realistic commercial option in certain areas because of the high seed yield potential and reduced costs of production for such crops. Tabo et al., (1995) observed commonly grown perennial types that remain in the field for two years among Nigerian traditional farmers. Studies on ratoonability in pigeonpea genotypes have been reported under Indian conditions (Sharma et al., 1978, Chauhan et al., 1996) but there is dearth of such information under the Nigerian condition. This study was carried out to assess the grain yield of improved and local pigeonpea genotypes under intercrop and sole crop conditions and the ratooning ability of the pigeonpea genotypes from such cropping systems.

\section{MATERIALS AND METHODS.}

An experiment was conducted using six pigeonpea genotypes of short-, medium- and long-duration types planted as sole crops and in mixtures with two maize genotypes in 2006 cropping season. The 2006 season pigeonpea crops were maintained as sole ratoon crops for the assessment of their ratoonability in the 2007 cropping season. The pigeonpea genotypes comprised of five improved genotypes of shortand medium-duration types obtained from the International Crops Research Institute for the Semi-Arid Tropics (ICRISAT) Kano station, Nigeria and a local Nsukka pigeonpea genotype of long-duration type obtained from Nsukka market. The ICRISAT genotypes were ICPL 87 and ICPL 161 (short-duration genotypes) and ICPL 85063, ICP 7120 and ICPL 87119 (medium-duration genotypes). The local pigeonpea genotype (Nsukka Local) was a longduration type. The two maize genotypes were hybrid maize (Oba Super II) and open pollinated maize (New Kaduna) both obtained at Molon Agro Services Enugu, Nigeria. The experiment was conducted in the Teaching and Research Farm of the Department of Crop Science, University of Nigeria Nsukka, (Latitude $6^{\circ} 52 \mathrm{~N}$ and longitude $7^{\circ} 24 \mathrm{E}$ and altitude $447 \mathrm{~m}$ above sea level). It is within the Low-land humid tropical agro-ecology of Nigeria. The six pigeonpea genotypes were combined with the two maize genotypes to obtain 12 pigeonpea/maize mixture treatments for two intercrop systems and were equally maintained as sole crop treatments for the sole crop system for the pigeonpea. The mixture teatments are as follows: $\mathrm{V}_{1} \mathrm{OM}=\mathrm{ICPL}$ 87/Open pollinated maize intercrop, $\mathrm{V}_{2} \mathrm{Om}=\mathrm{ICPL}$ 161/Open pollinated maize intercrop, $\quad \mathrm{V}_{3} \mathrm{Om}=\mathrm{ICPL}$ 85063/Open pollinated maize intercrop, $\mathrm{V}_{4} \mathrm{Om}=$ ICP 7120/Open pollinated maize intercrop, $\mathrm{V}_{5} \mathrm{Om}=$ ICPL 87119/Open pollinated maize intercrop, $\quad \mathrm{V}_{6} \mathrm{Om}=$ Nsukka Local/Open pollinated maize intercrop; while $\mathrm{V}_{1} \mathrm{Hm}=\mathrm{ICPL}$ 87/Hybrid maize intercrop, $\mathrm{V}_{2} \mathrm{Hm}=\mathrm{ICPL}$ 161/Hybrid maize intercrop, $\mathrm{V}_{3} \mathrm{Hm}=\mathrm{ICPL}$ 85063/Hybrid maize intercrop, $\mathrm{V}_{4} \mathrm{Hm}=\mathrm{ICP}$ 7120/Hybrid maize intercrop, $\mathrm{V}_{5} \mathrm{Hm}=\mathrm{ICPL}$ 87119/hybrid maize intercrop and $\mathrm{V}_{6} \mathrm{Hm}=$ Nsukka Local/Hybrid maize intercrop. The sole pigeonpea treatments were SV1=ICPL 87 sole crop, SV2=ICPL161 sole crop, SV3=ICPL 85063 sole crop, SV4=ICP 7120, SV5=ICPL 87119 sole crop and SV6=Nsukka Local sole crop.

The treatments were randomly allocated to treatment plots and laid out in randomized complete block design (RCBD) with three replications. Soil samples to a depth of 0$30 \mathrm{~cm}$ were taken with soil auger at random over the experimental land area at the beginning of the experiment. The samples were bulked and mixed thoroughly. A sub-sample was taken for characterization of the site.

The land for the experiment was ploughed, harrowed and ridged in July, 2006 at $1.0 \mathrm{~m}$ apart. It was marked out into three blocks with a spacing of $1.0 \mathrm{~m}$ between blocks and $1.0 \mathrm{~m}$ between plots. Each block had 18 plots each measuring $5.0 \mathrm{~m} \times 3.0 \mathrm{~m}=15 \mathrm{~m}^{2}$. The treatments were randomly assigned to the treatment plots in each block by use of Table of Random Numbers. Pigeonpea was planted on the two sides of the ridge at a spacing of $0.5 \mathrm{~m} \times 0.5 \mathrm{~m}$ giving 12 plants/ridge, equivalent to 40,000 plants per hectare. Maize was planted at the crest of the ridges at a spacing of $1 \mathrm{~m} \times 0.25 \mathrm{~m}$ giving 12 plants/ridge representing 40,000 plants/ha in the mixture treatments. The same plant population was used under both intercrop and sole crop systems in additive series.

Weed control was manually done by hoeing at 21 and 45 days after planting (DAP). In the Pigeonpea ratoon crops of 2007 cropping season, weeding was done manually in the months of May and August. Fertilizer application was done manually by banding at 3 weeks after planting and at the rate of $120 \mathrm{~kg} \mathrm{~N}$, $60 \mathrm{~kg} \mathrm{P}_{2} \mathrm{O}_{5}$ and $80 \mathrm{~kg} \mathrm{~K} \mathrm{~K}_{2} \mathrm{O}$ per hectare. Insect pests were controlled on the pigeonpea by spraying plants with "BEST Action" (Cypermethrin plus Dimathoate) at the rate of 1.5 litres/ha using knapsack sprayer. Spraying was done at $50 \%$ flowering and at podding stages of the pigeonpea in both the main and ratoon crops. 


\section{Data Collection and Analysis}

Five plants at the centre ridges of each plot were tagged and growth and yield data were taken on them. The number of primary branches and number of leaves per plant were taken on the pigeonpea at anthesis. Dry pods were harvested by hand picking for yield assessment.The grain yield was expressed as grain yield in $\mathrm{kg} / \mathrm{ha}$. The number of pigeonpea plants per plot that survived as ratoons were taken in the months of March and May in 2007. The percentage survival of ratoon crops were then obtained.

The data obtained were analysed for a randomized complete block design as outlined by Gomez and Gomez (1984) and Obi (2002). Genstat (3) Discovery software was used to implement the analyses. Detection of differences among treatment means for significant effect was by least significant difference (LSD) at $5 \%$ level of probability.

\section{RESULTS.}

The total monthly rainfalls $(\mathrm{mm})$ for 2006 and 2007 followed the characteristic bimodal pattern peaking first in the months of June and the second in October (Table 1). Rainfall was highest in June compared with no rainfall in December for 2006 and 2007. Rain always fell more frequently between June and October. During the periods of January, February, November and December rainfall was very low ranging from $0-55.1 \mathrm{~mm}$. The minimum and maximum air temperatures were rather high all through the period of the experiment. The
Relative Humidity (\%) followed closely from the rainfall pattern, rising with high rainfalls and decreasing with decreased rainfalls, being lowest in the months of November, December January and February. The Relative Humidity was always comparatively low in the months of December and January.

The soil of the experimental site was texturally sand clay loam and essentially acidic in reaction (Table 2). Phosphorus content was low in the site, while potassium, calcium and sodium were considered moderate.

Percentage ratoon plant survival in the pigeonpea was on the average $57.3 \%$ by the month of May 2007 when the rains had stabilized (Table 3). The two maize genotypes had different intercropping effects on the pigeonpea main crop plants. The percentage ratoon plants survival was significantly $(\mathrm{p}<0.05)$ higher in the pigeonpea plants that were intercropped with open pollinated maize in 2006 compared to those that were planted sole or intercropped with hybrid maize. Percentage ratoon plants survival was significantly $(\mathrm{p}<0.05)$ higher in the long-duration Nsukka Local genotype compared with the ICRISAT shortand medium-duration genotypes in both the months of March and May 2007. The ICRISAT short- and medium-duration genotypes did not differ significantly $(\mathrm{p}<0.05)$ in percentage ratoon plants survival except for the medium-duration ICPL 85063 genotype which had significantly higher values in both months of March and May 2007.

Table 1: Metereological records for 2005, 2006 and 2007 at Nsukka, Nigeria.

\begin{tabular}{|c|c|c|c|c|c|c|c|c|c|c|c|c|}
\hline & Jan & Feb & Mar & Apr & May & Jun & Jul & Aug & Sept & Oct & Nov & Dec \\
\hline \multicolumn{12}{|l|}{ records } & \\
\hline Total rainfall (mm) & 36.3 & 4.0 & 103.1 & 51.0 & 243.8 & 259.6 & 213.8 & 195.5 & 190.5 & 313.9 & 1.5 & 0 \\
\hline Rain days (No.) & 1 & 2 & 4 & 5 & 16 & 16 & 21 & 19 & 25 & 19 & 1 & 0 \\
\hline Max. air temp $\left({ }^{\circ} \mathrm{C}\right)$ & 33.1 & 33.6 & 33.1 & 35.5 & 30.5 & 29.9 & 28.6 & 27.8 & 28.1 & 29.9 & 31.7 & 32.6 \\
\hline Min. air temp $\left({ }^{\circ} \mathrm{C}\right)$ & 23.0 & 23.2 & 22.8 & 23.3 & 21.3 & 21.2 & 21.5 & 20.8 & 21.3 & 21.2 & 18.9 & 17.9 \\
\hline Relative Hum (\%) & 66.5 & 67.8 & 67.6 & 68.2 & 74.4 & 74.9 & 76.8 & 77.4 & 76.7 & 74.8 & 60.8 & 50.0 \\
\hline 2007 Weather & & & & & & & & & & & & \\
\hline \multicolumn{13}{|l|}{ records } \\
\hline Total rainfall (mm) & 0 & 9.9 & 39.1 & 121.6 & 193.5 & 327.6 & 62.9 & 323.6 & 169.6 & 267.2 & 55.1 & 0 \\
\hline Rain days (No.) & 0 & 1 & 4 & 8 & 11 & 16 & 14 & 17 & 19 & 18 & 4 & 0 \\
\hline Max. air temp $\left({ }^{\circ} \mathrm{C}\right)$ & 33.2 & 35.0 & 35.1 & 32.6 & 31.1 & 29.3 & 28.5 & 27.6 & 28.2 & 29.5 & 30.4 & 31.6 \\
\hline Min. air temp $\left({ }^{\circ} \mathrm{C}\right)$ & 20.8 & 22.6 & 23.1 & 22.9 & 21.8 & 21.8 & 21.2 & 21.8 & 21.3 & 20.7 & 21.3 & 20.0 \\
\hline Relative Hum (\%) & 57.5 & 64.3 & 67.1 & 69.2 & 73.9 & 74.8 & 76.9 & 76.9 & 76.9 & 73.8 & 66.2 & 63.1 \\
\hline
\end{tabular}


Table 2: Physical and chemical characteristics of the experimental site before planting

\begin{tabular}{ll}
\hline Mechanical properties: & $\mathbf{2 0 0 6}$ \\
Clay $(\%($ & 21.04 \\
\hline Silt $(\%)$ & 10.56 \\
Fine sand $(\%)$ & 18.36 \\
Coarse sand $(\%)$ & 50.04 \\
Textural class & Sandy clay loam \\
Chemical Properties & \\
pH in $\mathrm{H}_{2} \mathrm{O}$ & 5.1 \\
pH in $\mathrm{KCl}$ & 4.9 \\
Organic matter: & \\
Carbon $(\%)$ & 0.63 \\
$\mathrm{Nitrogen}(\%)$ & 0.068 \\
Exchangeable bases (meq/100g) & \\
$\mathrm{Na}$ & 0.66 \\
$\mathrm{~K}$ & 0.37 \\
$\mathrm{Ca}$ & 0.80 \\
$\mathrm{Mg}$ & 0.96 \\
$\mathrm{CEC}$ & 1.12 \\
$\mathrm{P}($ ppm) & 26.87 \\
\hline
\end{tabular}

Table 3: Pigeonpea ratoon crop percentage plant survival.

\begin{tabular}{|c|c|c|c|c|c|}
\hline \multirow{2}{*}{$\begin{array}{l}\text { Pigeonpea } \\
\text { Genotypes }\end{array}$} & \multicolumn{5}{|c|}{ Previous Cropping system } \\
\hline & P/pea & P/pea & Sole & Mean & \\
\hline & $\begin{array}{l}+ \\
\mathrm{Hm}\end{array}$ & $\begin{array}{l}+ \\
\text { Opm }\end{array}$ & P/pea & & \\
\hline \multicolumn{6}{|c|}{$\begin{array}{l}\text { March (2007) \% plant survival } \\
\text { SD types }\end{array}$} \\
\hline ICPL87 & 60.0 & 73.4 & 62.7 & 65.3 & \\
\hline ICPL161 & 60.7 & 64.9 & 56.7 & 60.8 & \\
\hline \multicolumn{6}{|l|}{ MD types } \\
\hline ICPL85063 & 69.6 & 65.8 & 66.9 & 67.5 & \\
\hline ICP7120 & 58.4 & 56.2 & 53.3 & 56.0 & \\
\hline ICPL87119 & 62.4 & 66.5 & 49.9 & 59.3 & \\
\hline \multicolumn{6}{|l|}{ LD type } \\
\hline Nsukka Local & 81.4 & 86.9 & 90.0 & 86.1 & \\
\hline Mean & 65.3 & 69.0 & 63.2 & 65.8 & \\
\hline \multicolumn{6}{|c|}{$\begin{array}{l}\text { May } 2007 \% \text { plant survival. } \\
\text { SD types }\end{array}$} \\
\hline ICPL87 & 54.5 & 66.8 & 52.9 & 58.1 & \\
\hline \multicolumn{6}{|l|}{ MD types } \\
\hline ICPL85063 & 63.0 & 63.9 & 57.1 & 61.3 & \\
\hline ICP7120 & 46.4 & 47.5 & 45.1 & 46.4 & \\
\hline \multicolumn{6}{|l|}{ LD type } \\
\hline Nsukka Local & 74.1 & 76.3 & 73.6 & 74.7 & \\
\hline \multirow[t]{2}{*}{ Mean } & 56.7 & 61.5 & 53.7 & 57.3 & \\
\hline & & & \multicolumn{2}{|c|}{ March \%plt. Surv } & May \% plt. surv. \\
\hline \multirow{2}{*}{\multicolumn{3}{|c|}{$\begin{array}{l}\operatorname{Lsd}_{0.05} \text { for } 2 \text { crop. sys. means } \\
\mathrm{Lsd}_{0.05} \text { for } 2 \text { p/pea geno. Means }\end{array}$}} & \multirow{2}{*}{\multicolumn{2}{|c|}{$\begin{array}{l}4.12 \\
5.83\end{array}$}} & 4.69 \\
\hline & & & & & 6.64 \\
\hline
\end{tabular}


Dasbak, M.A.D. and Asiegbu J.E.

Table 4: Effects of intercropping on number of primary branches/plant and number of leaves/plant in six pigeonpea genotypes main crops.

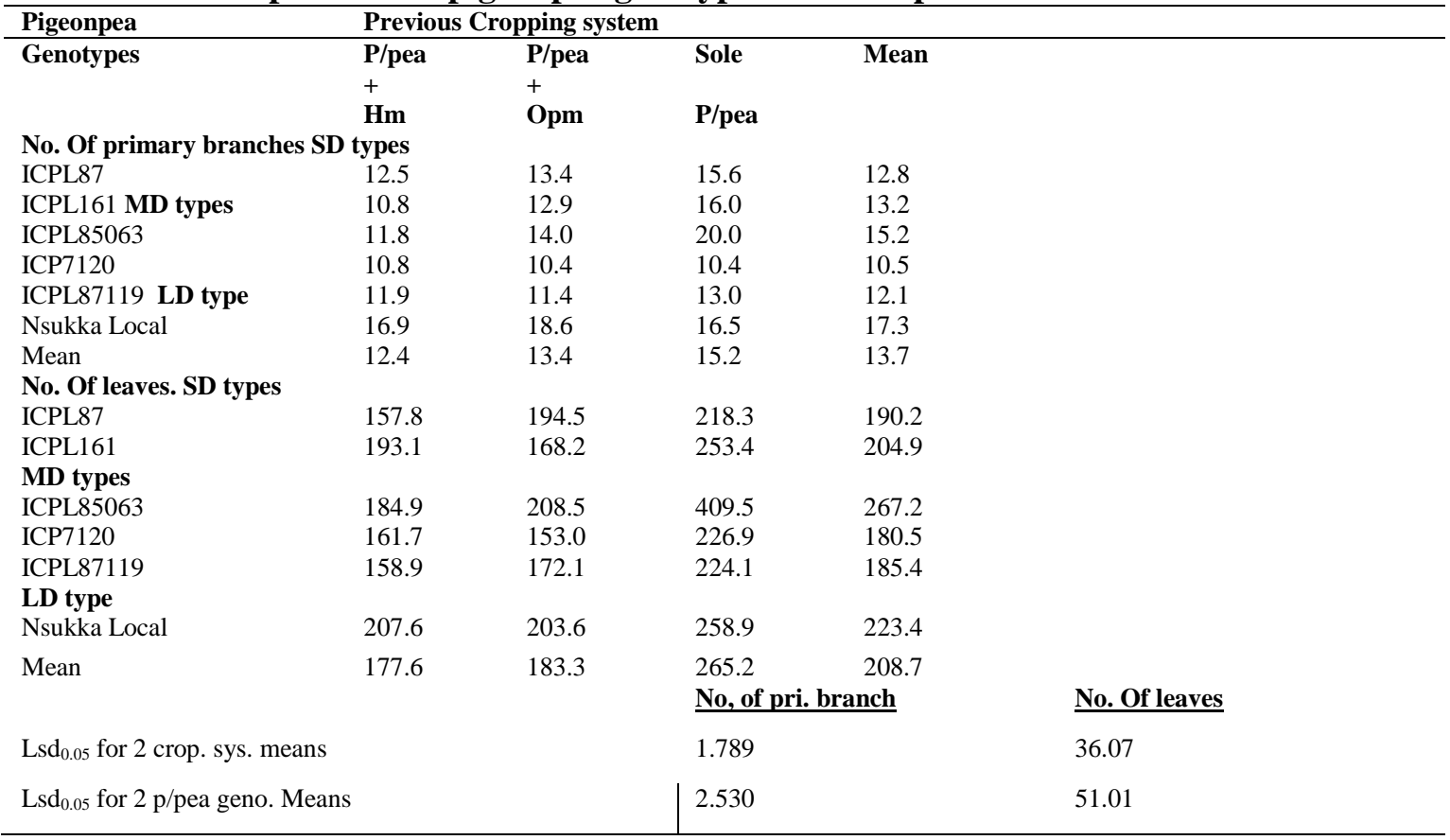

Table 5: Grain yield (kg/ha) in Pigeonpea main and ratoon crops.

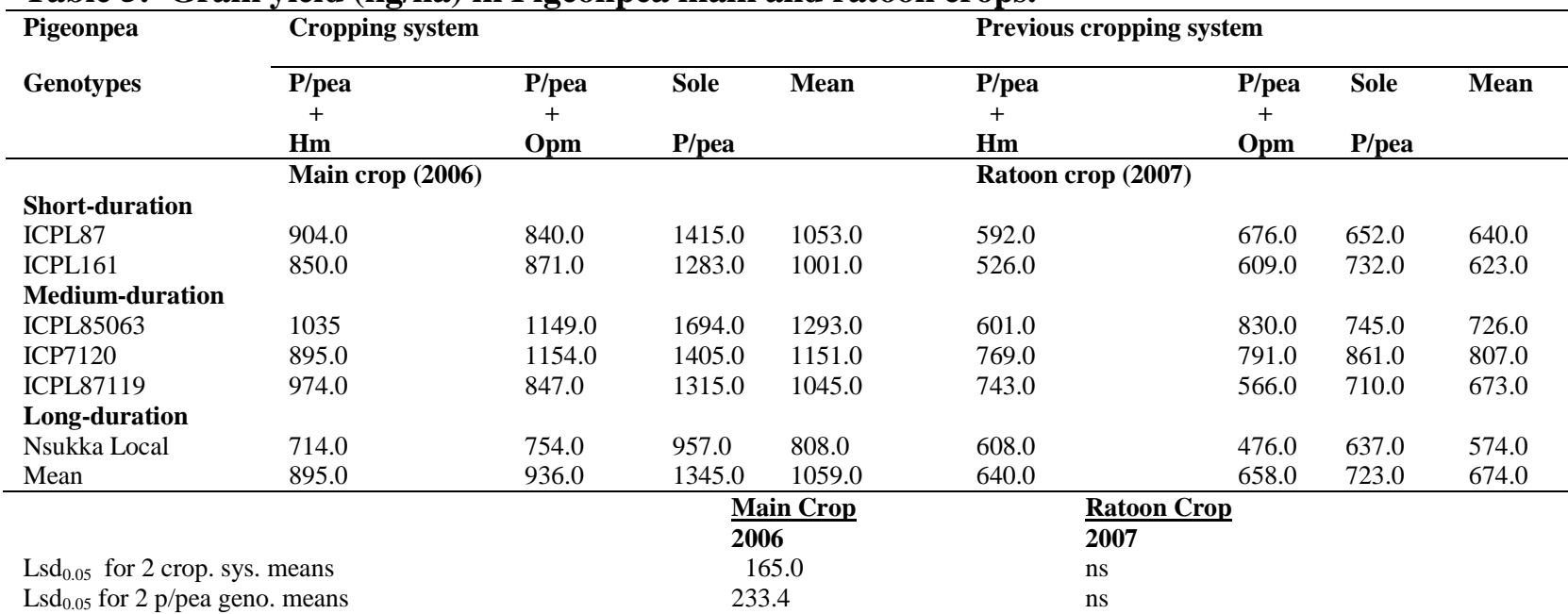

The number of primary branches and and number of leaves of pigeonpea were significantly $\quad(\mathrm{P}<0.05) \quad$ reduced under intercropping with maize compared with sole pigeonpea in the main crop (Table 4). Hybrid maize depressed the se parameters more in pigeonpea compared with open pollinated maize. The pigeonpea genotypes differed in their number of primary branches and leaves either with sole cropping or in intercropping system. Nsukka Local genotype had significantly
$(\mathrm{P}<0.05)$ higher number of primary branches than the ICRISAT pigeonpea genotypes. The variation in number of leaves among the pigeonpea genotypes did not show a definite pattern. ICPL 85063 had the highest and significantly different number of leaves compared with other ICRISAT genotypes and it was followed by Nsukka Local. The number of primary branches and leaves were always higher under sole cropping for all the pigeonpea genotypes. 
Grain yield in pigeonpea was higher in the main crops compared to the ratoon crops (Table 5). On the average, the grain yield in the ratoon crops was $63.6 \%$ of that of the main crop. Maize intercropping of pigeonpea significantly $(\mathrm{P}<0.05)$ depressed grain yield in the pigeonpea main crop. The ratoon crops had slightly higher grain yield in those that were initially planted as sole crops compared to those that were intercropped with maize. The pigeonpea genotypes differed significantly in their grain yield in the main crops but there was no significant difference among them in the ratoon crops. The ICRISAT short- and medium-duration genotypes yielded higher compared to the long-duration Nsukka Local genotype both in the main and ratoon crops. However, the medium-duration genotypes on the average yielded higher than the shortduration genotypes in both the main and ratoon crops. The grain yield in the the pigeonpea genotypes was medium-duration genotypes>short-duration genotypes>long-duration genotypes.

\section{DISCUSSION.}

The high rainfall in the months of July to October and the minimum and maximum temperature ranges from $20.3-21.5^{\circ} \mathrm{C}$ and $27.4-30.1^{\circ} \mathrm{C}$ in this study were within the requirements for both the maize and pigeonpea crops as reported by Purseglove (1972) and van der Maesen (1989). The drop in rainfall and relative humidity in the months of November and December coincided with flowering and maturity periods for pigeonpea and was good for the pod harvest. The slightly acidic sandy clay loam nature of the soil was within the tolerable limits for both the maize (IITA, 2007) and pigeonpea crops (Bogdan, 1977, and van der Maesen 1989). The soil has been classified as an ultisol (Asiegbu, 1989).

The dry season is a dry period between two cropping seasons and its duration and effect on crop plants vary across ecological zones in Nigeria. The high percentage survival of the pigeonpea ratoon plants in this study was attributed to the perennial nature of the pigeonpea (Snapp et al., 2003 and Wallis et al., 1987), and its deep and extensive vertical tap root with multiple branches (Anderson et al., 2001). Whiteman et al., (1985) reported that pigeonpea has outstanding ability to tolerate drought and can recover after severe environmental or biotic stress. The humid tropical condition of Nsukka with a record of $9.9 \mathrm{~mm}$ and $39.1 \mathrm{~mm}$ rainfall within the dry season months of February and March 2007 as shown in table 1 was considered contributory for the high survival of the ratoon crops too. The lower ratoon plant survival in those that were intercropped with hybrid maize was attributed to the stress effect from the highly competitive hybrid maize on the main crop. The high plant looses in sole cropped pigeonpea plants was attributed to the high competition among its robust plants under the dry season condition thereby leading to some plant losses. The high percentage survival in Nsukka Local pigeonpea genotype was attributed to its long-duration nature as it matured late into the dry season with little time left to the next cropping season. This enhanced its chances to survive into the next cropping season compared with the short- and mediumduration genotypes which matured early with longer periods to the next cropping season. The slightly lower percentage plant survival in ICP 7120, ICPL 87119 (medium-duration) and ICPL 161 (short-duration) compared with the relatively higher percentage plant survival in ICPL 87(short-duration) and ICPL 85063 (medium-duration) implied no marked difference among the ICRISAT short- and medium-duration genotypes in ratoon crop survival under the humid tropical condition of this study.

The significant reduction in the number of primary branches and number of leaves in pigeonpea due to maize intercropping was attributed to the domineering effect of maize in the intercropping system over the slow establishing pigeonpea in their early vegetative stage and it agrees with report by Snapp et al; (2003). The faster development in the maize crop should have led to fast leaf development and expansion culminating in shading the pigeonpea crop thereby affecting these parameters. The high plant density under the pigeonpea/maize mixtures reduced the number of branches as similarly reported by Akinola and Whiteman (1975) compared with their sole cropped counterparts.

The higher pigeonpea grain yield in the main crops compared with their ratoon crops was attributed to higher plant vigor in the main crops. The $63.6 \%$ average ratoon crop yield of the main crop in this study was higher than the $50 \%$ ratoon crop yield reported in some short-duration pigeonpea genotypes by Chauhan et al., (1996) in India.

The minimal previous maize intercropping effect on the ratoon crops implied that pigeonpea ratoon crops have the potential to recover from the stress effect of their previous intercrops when maintained as sole ratoon crops. This agrees with report by Snapp et al., (2003) that cereals intercropped with long-duration pigeonpea are generally harvested toward the end of the rainy season, and the pigeonpea develops rapidly on residual moisture after the harvest of the companion crop and in some areas ratoon system is used for a second crop harvested in the subsequent season. This agrees with Chauhan et al., (1996) who reported significantly positive relationship of total ratoon yield to main crop yield. The higher grain yield in the ICRISAT medium- and short-duration genotypes compared with the Nsukka Local genotype under main crop and ratoon crop conditions were attributed to their 
genotypic characteristic high yield attributes for which they were bred (Upadhyaya et al., 2006). The higher grain yields exhited by ICPL 85063 and ICP 7120 of the medium-duration genotypes under both main and ratoon crops implied their yield superiority compared with the other pigeonpea genotypes in this study.

\section{CONCLUSION.}

The higher grain yield in the ICRISAT shortand medium-duration genotypes both in intercropping system with maize genotypes and as sole crops in the main crop compared with the long-duration genotype implied great potential for their adoption by the traditional farmers to replace their low yielding longduration genotypes. The high percentage plant survival and grain yield in the ratoon crops of the pigeonpea genotypes in this study was indicative of their ratoonability under the humid tropical agro-ecology. With the higher grain yield in the medium-duration pigeonpea genotypes in intercrop mixtures with maizes in the main crop and in the ratoon crops compared to the short-duration genotypes; it can be concluded that the medium-duration genotypes are most suitable for adoption under both main and ratoon crop production for greater benefits to farmers.

\section{ACKNOWLEDGEMENT.}

The improvement of pigeonpea genotypes and release by the International Crops Research Institute for the Semi-Arid Tropics (ICRISAT) for this study is appreciated. The provision of land and other facilities by the Department of Crop Science, University of Nigeria Nsukka for the study is also appreciated.

\section{REFERENCE}

Akinola, J. O. And Whiteman, P. C. (1975). Agronomic Studies on Pigeonpea. Field Responses to sowing time. Aust. Agric Res. 23:43-56.

Anderson, S., S. Gundel. B.Triamphe. (2001). Cover crops in small holder agriculture; Lessons from Latin America. Internediate Technology Development Group (ITDG) Publishing, U. K.

Asiegbu, J. E. (1989). Responses of onion to lime and fertilizer $\mathrm{N}$ in a tropical ultisol. Tropical Agric. (Trinidad) (2) 66: 161-166.

Bogdan, A. V. (1977). Tropical Pasture and Fodder Plants. Longman Inc., New York pp. 325328.

Borget Marc. (1992). Food Legumes. The Tropical Agriculturalist. Rene Coste (editor). First Edition Macmillan Publishers. Pp 13-84.

Chauhan, Y. S., C. Johansen, S. C. Gupta. (1996). Assessment of ratoonability of short- duration pigeonpea genotypes. Journal of Agricultural Science. Vol. 127 (3), pp 331335.

Gomez, K. A. and A. A. Gomez (1984). Statistical Procedures for Agricultural Research. $2^{\text {nd }}$ Edition. A Wiley Interscience Publication pp 8-29, 89-233.

Guy, M., P. Kimani, A. Mwang' Ombe, F. Olubayo, C. Smith, P. Audi, J. Baudoin and A. Le Roi (2001): Survey of pigeonpea production systems, utilization and marketing in semiarid lands of Kenya. In: Biotechnol. Agron. Soc. Environ. 5(3). 145-153.

IITA (2007) Research for Development: Cereal and Legume-Maize. 1pp.

Lingaraju, B. S., S. B. Marer and S. S. Chandrashekar (2008). Studies on intercropping of maize and pigeonpea under rainfed conditions in Northern Transitional Zone of Karnataka. Karnataka J. Agric.Sci., 21 (1) (1-3) : 2008.

Obi, U. I. (2002). Statistical Methods of Detecting Differences Between Treatment Means and Research Methodology Issues in Laboratory and Field Experiments. Second Edition Published in Nigeria by AP Express Publishers Limited, 3 Obollo Road, NsukkaNigeria. 117pp.

Purseglove, J. W. (1972). Tropical CropsMononcotyledons. Longman (Singapore) Publishers. Pp.97-291.

Rao M.R. and Willey R.W., (1980). Evaluation of yield stability in intercropping studies on sorghum. Pigeon pea. Exp. Agric., 16, 105-166.

Sharma, D., K. B. Saxena, and J. M. Green, (1978). Potential of ratoonability in pigeonpea. Field Crops Research. 11: 165-172.

Snapp, S. S., Jones, R. B., Minja, E.M. Rusike, J. and S. N. Silim (2003). Pigeonpea for Africa: A versatile vegetable and more. Hort Science, Vol., 36(6), 1073-1078.

Tabo R., Ezueh, M. I. Ajayi, O., Asiegbu, J. E. and Laxman Singh (1995).Pigeonpea Production and Utilization in Nigeria. In: International Chickpea and Pigeonpea Newsletter No. 2 pp. 47-49.

Upadhyaya, H. D. , Reddy, L. J. Gowda, C. L. L. Reddy, K. N. and S. Singh. (2006) Development of a mini Core Subset for Enhanced and Diversified Utilization of pigeonpea Germplasm Resources. Crop Sci. 46: 2127-2132.

van der Maesen, L. J. G., (1989). Cajanus cajan (L.) Millsp. In:van der Maesen, L.J.G. and Somaatmadja, S. (Eds): Plant resources of South-East Asia No. 1 Pulses. Pudoe/Prosea, Wageningen, the Netherlands. Pp 39-42. 
Wallis, E. S. , D. E. Byth, and P. C. Whiteman (1981). Mechanized Dry Seed Production of Pigeonpea. In: ICRISAT ( International Crops Research Institute for the Semi-Arid Tropics). !981. Proceedings of the international workshop on pigeonpeas, Vol. 1, 15-19 Dec. 1980, Patencheru, India. Publication Editor Vrinda Kumble. Pp 51-60.

Wallis, E. E., Woolcock, R. F. and D. E. Byth. (1987) Potential for Pigeonpea in Thailand, Indonesia and Burma.. CGPRET No. 15, 74 pp.
Whiteman, P. C. , D.E. Byth and E.E. Wallis(1985). Pigeonpea (Cajanus cajan(L.) Millsp.) In: Grain Legume crops (eds. Summerfield,R.J. Roberts,E. H.). First Edition. Published by Collins Professional and technical Books. Pp 658-698

Willey, R. W., Rao, M. R. and M. Natarajan (1981). Traditional cropping systems with pigeonpea and their improvement. In: Proceedings of the International workshop on pigeonpea. Vol.1, 15-19, December 1980, ICRISAT, India. 